\title{
Effects of Border Crops and Intercrops on Control of Cucurbit Virus Diseases
}

\author{
J. P. Damicone and J. V. Edelson, Department of Entomology and Plant Pathology, Oklahoma State University, \\ Stillwater 74078; J. L. Sherwood, Department of Plant Pathology, University of Georgia, Athens 30602; \\ L. D. Myers, USDA/ARS, Stillwater, OK; and J. E. Motes, Department of Horticulture and Landscape Architecture, \\ Oklahoma State University
}

\begin{abstract}
Damicone, J. P., Edelson, J. V., Sherwood, J. L., Myers, L. D., and Motes, J. E. 2007. Effects of border crops and intercrops on control of cucurbit virus diseases. Plant Dis. 91:509-516.

In five field trials over 3 years, control of aphid-transmitted, nonpersistent virus diseases on pumpkin, caused mostly by the potyviruses Watermelon mosaic virus (WMV) and Papaya ringspot virus type-W (PRSV-W), was achieved by intercropping with grain sorghum, as opposed to clean tillage. Reductions in disease incidence ranged from 43 to $96 \%(P \leq 0.05)$. Surrounding pumpkin plots with borders of peanut, soybean, or corn was not effective. Borders of grain sorghum were effective, but disease control was generally less than for the intercrop treatment. Intercropping soybean and peanut with pumpkin reduced disease incidence by 27 to $60 \%$ $(P \leq 0.05)$, but disease control generally was less than for grain sorghum. Peak periods of alate aphid immigration generally preceded virus disease outbreaks by 7 to 14 days. However, alate landing rates, as measured in green tile traps, did not differ among treatments. Marketable yield was not increased by the intercrop treatments, and yield was reduced by up to $50 \%$ for the intercrop treatment with grain sorghum in two trials. The use of grass-selective herbicide applied along pumpkin rows, reduced seeding rates of the intercrops, or mowing did not alleviate the adverse effects of competition between pumpkin and the grain sorghum intercrop on yield.
\end{abstract}

Virus diseases are important constraints on the production of cucurbit vegetable crops in the United States and worldwide. The potyviruses Watermelon mosaic virus (WMV) (5,24), Papaya ringspot virus type-W (PRSV-W) (23), and Zucchini yellow mosaic virus (ZYMV) $(18,19)$; and the cucumovirus Cucumber mosaic virus (CMV) (11) are found at varying levels wherever these crops are grown $(7,22,25,34)$. The viruses cause mosaic, mottling, enation, and puckering of foliage; mosaic and distortion of fruit; and plant stunting (27). Effects on yield can be severe, particularly where early infections severely stunt plants and where symptoms render fruit unmarketable. In viral disease outbreaks in Oklahoma and Texas, each of these viruses has been identified alone or in mixed infections, with WMV being the most frequently detected $(6,14,15,37)$.

The viruses are spread by aphids in a nonpersistent (stylet-borne) manner, and many species are involved in virus spread. Of the 38 aphid species known to transmit WMV $(22,24)$, only the melon/cotton aphid is considered a primary cucurbit pest. The other vectors are noncolonizing

Corresponding author: J. P. Damicone

E-mail: john.damicone@okstate.edu

Accepted for publication 31 October 2006.

doi:10.1094/PDIS-91-5-0509

(C) 2007 The American Phytopathological Society alates that move through crops searching for suitable feeding hosts. Aphid vectors acquire virus quickly while probing infected plants and remain infective for only short periods of time that vary from minutes to hours depending on temperature and feeding (21,30). Generally, viruliferous aphids transmit the virus to only one or a few plants before infectivity is lost (21).

There are limited options for managing virus diseases of cucurbits. Insecticide sprays against the aphid vectors are not effective in reducing virus disease because aphids transmit virus before the insecticides act to kill them $(16,20,28,36)$. Reflective film mulches of white or silver color have been effective in providing partial disease control by delaying the onset of virus epidemics $(6,13)$. A limitation of reflective films in cucurbits has been that plant growth rapidly covers the mulch and thereby lessens reflectivity. The application of row covers to summer squash until flowering was not effective in reducing virus disease, and caused some yield reduction (6). Frequent applications of mineral oil, which interferes with nonpersistent viral transmission, have been evaluated for virus disease control (29). In watermelons, biweekly applications of mineral oil delayed the time at which $50 \%$ of plants were infected with WMV or PRSV-W by 5 to 7 days, but did not increase yield compared with the untreated control (36). In melons, biweekly sprays of mineral oil reduced the incidence of plants infected with WMV and CMV from $69 \%$ in the unsprayed control to $52 \%$ in one trial but not in another, where virus incidence exceeded $90 \%$ for both sprayed and unsprayed treatments (35). Adoption of these management practices by growers has been limited because the labor and expense involved often do not outweigh the resulting small and inconsistent benefits.

The elimination of primary sources of virus inoculum by crop isolation in time and space, and by elimination of alternate hosts, are potential management strategies that have been successful for some virus diseases (30). In production areas of the southern United States, successive cucurbit crops grown during the spring, summer, and fall serve as sources of inoculum for subsequent crops. While important alternate hosts have been identified in Florida (1) and Texas (5), CMV and WMV have wide host ranges, making identification of important source species difficult. Furthermore, viruliferous alate aphids may immigrate into fields from a distance, making the elimination of alternate hosts impractical.

The availability of genetic resistance to virus diseases in cucurbits is limited to cucumber and a few squash cultivars. Transgenic resistance achieved through the genetic transformation of plants with viral coat protein genes has led to the release of several squash cultivars with resistance to one or more viruses (12). In Oklahoma, the effectiveness of transgenic squash cultivars for virus disease control has been limited because PSRV-W resistance was lacking.

Based on the behavior of alate aphids that transmit virus diseases, conventional cropping practices for cucurbit production favor virus disease outbreaks. Because none of the major virus diseases described above are seedborne in cucurbits (27), the viruses are introduced into fields from external sources. Under low wind conditions, low-flying alates searching for feeding hosts are attracted to long wavelength light reflected from contrasting edges of soil and plant interfaces, i.e., isolated patches of vegetation bordered by bare ground $(17,20)$. As a result, occurrence of virus disease is increased in fields where plant density is low $(17,31,32)$. Generally, cucurbit plants are widely spaced both within and between rows and are particularly attractive to alates searching for suitable hosts. Under windy conditions, wind direction and landscape influence the dis- 
tribution of alate aphids, and they often accumulate on the leeward side of structural and vegetative windbreaks (17). Thus, occurrence of aphid-transmitted virus disease is often highest near the edges of a field $(1,8,22,31)$.

The manipulation of vegetation patterns has been used as a cultural control strategy to reduce the attractiveness of crop plants to alate aphids or to intercept incoming alates in alternate, nonhost crops where infectivity might be lost during probing. Use of a border crop to form a screen around the main crop has provided protection against several nonpersistent virus diseases. Significant $(>50 \%)$ reductions in Potato virus $Y$ (PVY) have been achieved in pepper with borders of sunflower (28); and in potato with borders of sorghum, soybean, and wheat (8). Similar reductions in the incidence of Bean yellow mosaic virus in broad bean were observed with border strips of barley (16). In some cropping systems, border crops taller than the main crop have been most effective $(17,28)$. However, border crops of differing heights were equally effective in protecting potato (8). Other studies have reported only modest levels of disease control following deployment of crop borders. Borders of sorghum, corn, and vetch were recently evaluated to protect peppers from CMV and PVY (10). The sorghum and vetch borders were effective in only 2 of 4 years, and the level of disease control was less than $15 \%$. The effectiveness of border crops in managing virus diseases of cucurbits has not been reported.

Intercropping, the culture of another crop in close proximity to the main crop, either in alternating rows or as a groundcover between rows of the main crop, has also been evaluated for effects on nonpersistent virus diseases. Intercropping with corn reduced incidence of Turnip mosaic virus in radish by $90 \%$ (13), and intercropping soybean with dwarf or tall sorghums reduced seed mottling from Soybean mosaic virus (SMV) by $50 \%$ (3). Planting cereal crops in and around sugar beets has been effective in reducing virus diseases and has been commercially practiced in Europe (32). Wheat and Swiss chard planted in and around muskmelon reduced the incidence of potyviruses by $90 \%$ (33). However, the cool-season intercrops evaluated for virus protection in muskmelon are not adapted for growth during the summer months in the southern United States. The objective of this research was to evaluate the effectiveness of warm-season companion crops, planted in border and intercrop patterns with cucurbits, for control of nonpersistent virus diseases.

\section{MATERIALS AND METHODS}

Experiments that evaluated the effectiveness of border crops and intercrops were conducted at the Oklahoma Vegetable Research Station at Bixby during 1996 to 1998 and at the Wes Watkins Agricultural Research and Education Center in Lane, OK, during 1997 to 1998. Pumpkins were used as the cucurbit crop in each experiment because virus symptoms are overtly expressed and the crop is grown during the summer and fall when virus diseases typically reach high levels.

Field experiments. In 1996 at Bixby, border crops of corn, soybean, and peanut, and an intercrop of grain sorghum, were compared with conventionally planted pumpkin for virus disease control. In addition to being nonhosts of the cucurbit viruses, the companion crops were selected based on their heat tolerance, differential plant heights, and herbicide compatibility with pumpkin. The experimental design was a randomized complete block with three replications. Granular fertilizer at 36$36-36 \mathrm{~kg} / \mathrm{ha} \mathrm{N}-\mathrm{P}-\mathrm{K}$ was incorporated into the soil prior to planting pumpkins and companion crops on 10 July. Plots were $18.2 \times 18.2 \mathrm{~m}$, and each contained three

\section{Border}
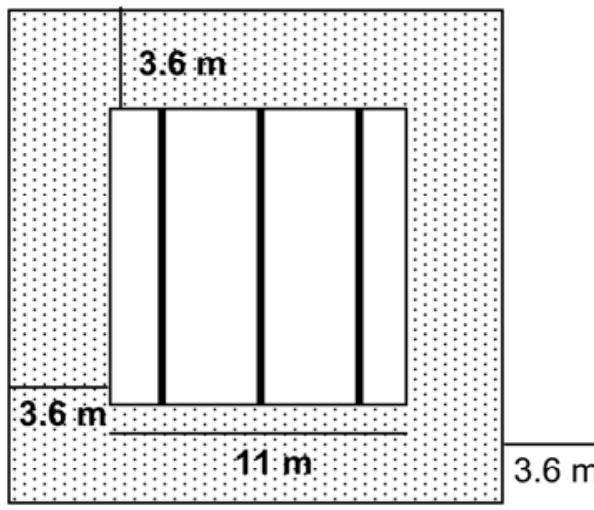

$$
\text { | = Pumpkin }
$$

\section{Intercrop}

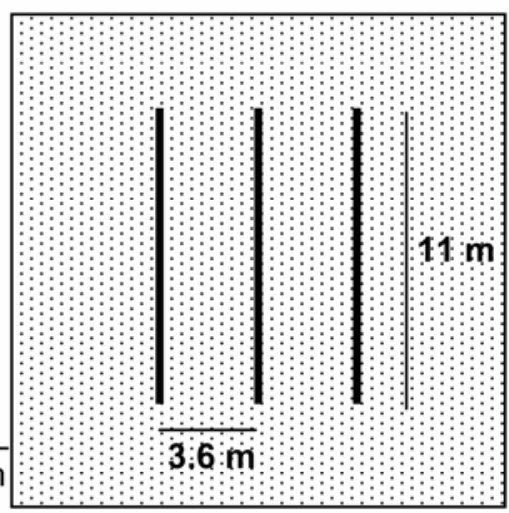

= Companion crop

Fig. 1. Plot design for assessing the impact of companion crops planted in border and intercrop patterns with pumpkin on virus diseases of pumpkin.

11-m-long rows of pumpkin (cv. Connecticut Field) spaced $3.6 \mathrm{~m}$ apart (Fig. 1). Border crops of corn (cv. Fantasia), peanuts (cv. Tamspan 90), and soybean (cv. Choska, Group VI) were planted in rows on $0.91-\mathrm{m}$ centers around the plot perimeter in a 3.6-m-wide strip. The intercrop of grain sorghum (cv. SG-833) was established by broadcasting seed at $56 \mathrm{~kg} / \mathrm{ha}$ and incorporating it with light tillage. Conventionally planted pumpkins were seeded into bare ground and served as the control. The pre-emergence herbicide Smetolachlor at $1.12 \mathrm{~kg} / \mathrm{ha}$ was broadcast immediately after planting for weed control. The plots were lightly irrigated to promote emergence and activate the herbicide within $24 \mathrm{~h}$ of planting. After emergence, pumpkins were thinned to a withinrow spacing of approximately $0.6 \mathrm{~m}$. Plots were top-dressed with additional granular fertilizer at $56-0-0 \mathrm{~kg} / \mathrm{ha} \mathrm{N}-\mathrm{P}-\mathrm{K}$ on 20 July. To alleviate potential competition effects between pumpkins and the grain sorghum intercrop, the grass-selective herbicide fluazifop-P-butyl at $0.28 \mathrm{~kg} / \mathrm{ha}$ plus $0.25 \%$ nonionic surfactant was sprayed over the pumpkin rows in a 0.91 -m-wide band on 25 July and in a 1.8-m-wide band on 10 August. Squash bugs were controlled in all plots with permethrin at $0.22 \mathrm{~kg} / \mathrm{ha}$ on 14 August and 31 August. Sprinkler irrigation was applied as needed to prevent moisture stress. Yields were taken on 30 September.

Based on the results from 1996, during which only the intercrop treatment with grain sorghum reduced virus disease incidence, treatments in 1997 focused on the use of grain sorghum in border and intercrop patterns compared with conventionally planted pumpkins. To evaluate the effects of early establishment of the border and intercrops on virus disease control, grain sorghum was planted 2 weeks before (early planted) and on the date of pumpkin planting (late planted). In the intercrop treatments, competition between the intercrop and pumpkins was reduced in both the early and late planting dates with grass-selective herbicide as in 1996, and by mowing in the late planting date.

In 1997, the trials were conducted at both Bixby and Lane using the same plot dimensions (Fig. 1), fertilizer program, seeding rates and methods, row and plant spacings, and herbicide and insecticide rates as in 1996. Early-planted borders and intercrops of grain sorghum (cv. Oro-DXtra) were planted on 5 June at Bixby and 15 June at Lane. Pre-emergence herbicide was broadcast over areas of each plot planted with grain sorghum immediately after planting. Late-planted borders and intercrops of grain sorghum, and pumpkins (cv. Aspen) in all plots were planted on 23 June at Bixby and on 1 July at Lane. Preemergence herbicide was broadcast over entire late-planted and control plots, and over the area within the grain sorghum border for the early-planted border treat- 
ment immediately after planting. Grassselective herbicide was applied in a 0.91m-wide band over the pumpkin rows of each an early and a late-planted intercrop treatment on 14 July at Bixby and 18 July at Lane, and in a 1.8 -m-wide band on 2 August at Bixby and on 30 July at Lane. For the other late-planted intercrop treatment, the grain sorghum was mowed to a height of approximately $15 \mathrm{~cm}$ around the pumpkin rows on 17 July, 23 July, and 2 August at Bixby and on 22 July and $5 \mathrm{Au}-$ gust at Lane. The mowed plots also received grass-selective herbicide in a 0.91m-wide band over the pumpkin rows on 2 August at Bixby and on 30 July at Lane. Plots were not irrigated because rainfall was adequate for pumpkin growth at both locations. Yield was taken at Lane on 9 October.

Because intercrop treatments had the greatest effect on virus disease incidence in 1996 and 1997, intercrops of peanuts (cv. Georgia Green), grain sorghum (cv. Oro-D-Xtra), and soybeans (cv. Midland VNS, MG 3.8) were compared with conventionally planted pumpkin in 1998. Each intercrop was planted at high and low seeding rates to assess the effects of intercrop density on virus disease control and competition between crops. Not only were companion crops selected for herbicide and heat tolerance, but also as a means for reducing competition. Georgia Green was selected as a peanut cultivar because of its flat and compact plant stature. Earlymaturing soybeans (maturity group 3.8) were selected for their short stature and early senescence at the planting dates used. The trials were conducted at both Bixby and Lane using the same experimental design, planting pattern (Fig. 1), fertility and pre-emergence herbicide programs, and insecticide rate as described above.

In 1998, intercrops and pumpkins (cv. Aspen) were planted on 23 June at Bixby and on 30 June at Lane. Companion crops were established by broadcasting seed over the entire plot area followed by incorporation with light tillage. The high and low seeding rates for the intercrops were 56 and $22 \mathrm{~kg} / \mathrm{ha}$. All plots received a preemergence herbicide application of $\mathrm{S}$ metolachlor immediately after planting, and plots were irrigated within $24 \mathrm{~h}$. Squash bugs were controlled at Lane with permethrin on 14 August, 21 August, 28 August, and 4 September. Plots were watered by sprinkler irrigation as needed at both locations. Pumpkins were harvested on 30 September at Bixby and on 13 October at Lane.

Virus disease identification and evaluation. All pumpkin plants in each plot were monitored weekly for virus symptoms. Plants with symptoms of virus disease (mosaic or mottling, veinbanding, leaf and plant stunting, enation, blistering, and/or leaf distortion) were marked with a surveyor's flag, and a terminal leaf sample was taken, stored on ice, and returned to the lab. Each sample was assayed for virus infection by enzyme-linked immunosorbent assay (ELISA) (9) using ELISA kits (Agdia, Inc., Elkhart, IN). ZYMV and WMV were assayed using indirect ELISA. CMV, PRSV-W, and the comovirus Squash mosaic virus (SqMV) were tested using double antibody sandwich ELISA (DASELISA). SqMV is a beetle- and seedtransmitted virus (4) that has occasionally been found in cucurbits in Oklahoma. For the indirect ELISA, plant sap was diluted $1: 10$ in carbonate-bicarbonate buffer $\left(0.035 \mathrm{M} \mathrm{NaHCO}_{3}, 0.015 \mathrm{M} \mathrm{Na}_{2} \mathrm{CO}_{3}\right)+$ $2 \%$ polyvinylpyrrolidone (PVP), $\mathrm{pH} 9.6$, and incubated in wells for $1 \mathrm{~h}$. A 1:200 dilution of antibody in ECL buffer (phosphate buffered saline $[(0.14 \mathrm{M} \mathrm{NaCl}, 0.008$ $\mathrm{M} \mathrm{Na} \mathrm{HPO}_{4}, 0.0015 \mathrm{M} \mathrm{KH}_{2} \mathrm{PO}_{4}, 0.27 \mathrm{M}$ $\mathrm{KCl})+0.05 \%$ Tween $20($ PBST $)]+0.2 \%$ bovine serum albumin and $2 \% \mathrm{PVP}$ ), $\mathrm{pH}$ 7.4 , was added and incubated for $2 \mathrm{~h}$. A 1:200 dilution of alkaline phosphatase conjugate in ECL buffer was added and incubated for $1 \mathrm{~h}$. For DAS-ELISA, wells were loaded with a 1:200 dilution of antibody in carbonate-bicarbonate buffer and incubated overnight at $4^{\circ} \mathrm{C}$. A 1:10 dilution of plant sap in PBST buffer $+0.1 \mathrm{M}$ $\mathrm{Na}_{2} \mathrm{SO}_{3}, 2.05 \%$ Tween 20, and 2\% PVP, $\mathrm{pH} 7.4$, was added and incubated for $2 \mathrm{~h}$. A 1:200 dilution of alkaline phosphatase conjugate in ECL buffer was then added and incubated for $2 \mathrm{~h}$. For both ELISA procedures, substrate $(1 \mathrm{mg} p$-nitrophenyl phosphate/ml substrate buffer $[0.001 \mathrm{M}$ $\mathrm{MgCl}+10 \%$ diethanolamine]), $\mathrm{pH} 9.8$, was added and absorbance values were read after 30 to $60 \mathrm{~min}$ at $405 \mathrm{~nm}$. Unless otherwise noted, all incubations were at room temperature and wells were washed three times between steps with PBST buffer, $\mathrm{pH}$ 7.4. Each plate included positive and negative controls, and samples were considered positive when absorbance values were more than $10 \times$ above the negative control. For each sampling date, the incidence of virus-infected plants was determined by dividing the number of plants per plot that had virus symptoms and tested positive by ELISA by the total number of plants per plot. The area under the disease progress curve (AUDPC) was then calculated for each plot (26). At harvest, each fruit was classified as diseased or healthy based on the presence or absence of green mottling, knobby swellings, and/or shape deformation. Yield of healthy, diseased, total fruit was expressed by weight.

Alate aphid immigration. In 1997 and 1998, the landing of alate aphids in plots was quantified using green ceramic tile traps (8). Sandwich-size plastic containers were held in wire frames attached to a wooden stake and placed so that the trap was above the foliage at a height of $0.9 \mathrm{~m}$ in the center of each plot. A single $11-\mathrm{cm}^{2}$ ceramic tile, painted with epoxy paint formulated to match the color of a D-22 green tile (Dal-Tile Corp., Mexico), was placed in each container, and the trap was filled with a $50 \%$ aqueous solution propylene glycol. The green tile mimics foliage and the trap provides an estimate of passive alate landing. The traps were changed once per week, and aphids were counted under a dissecting microscope. Aphid landing rates were expressed as the average weekly trap catch $(8,10)$.

Statistical analysis. Data on disease incidence, AUDPC, average weekly trap catches, and yield were analyzed by analysis of variance using the GENERAL LINEAR MODELS procedure of SAS (Version 9.1; SAS Institute, Cary, NC). Experiments were analyzed individually because some of the treatments differed over years, and treatments $\times$ location interactions were significant $(P \leq 0.05)$ for several variables within years. Means were separated with Fisher's least significant difference test where indicated by significant treatment effects in the analysis of variance model. Unless otherwise indicated, only significant differences $(P \leq$ 0.05 ) are described below.

\section{RESULTS}

Bixby - 1996. PRSV-W and WMV were the predominant viruses detected by ELISA. Most (50\%) of the 244 symptomatic plants tested were positive for both PRSV-W and WMV. PSRV-W and WMV were detected alone in 21 and $19 \%$, respectively, of the plants. ZYMV and SqMV were detected in 6 and $4 \%$ of the plants, respectively, and generally in combination with PRSV-W and or WMV.

In the control treatment, virus disease appeared on 5 August and increased to an incidence of $100 \%$ by 12 September (Fig. 2 ). The appearance of virus disease was delayed by approximately 14 days for the intercrop treatment with grain sorghum compared with the control. The times of virus disease appearance and disease increase in plots surrounded by borders of corn, soybean, and peanut were similar to those of the control. AUDPC and final

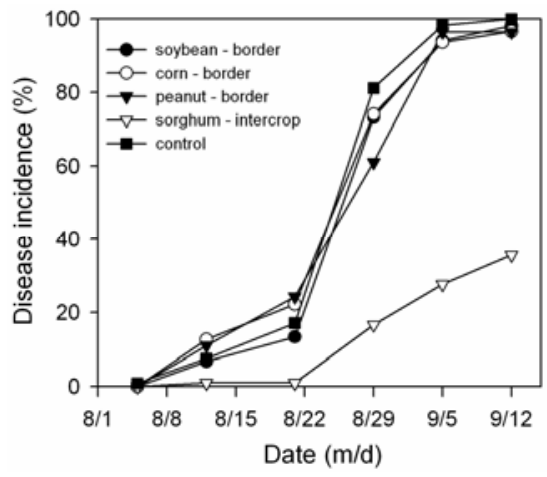

Fig. 2. Effects of companion crops planted in border and intercrop patterns with pumpkin on progress of virus diseases of pumpkin at Bixby in 1996. 
disease incidence were reduced compared with the control by over $60 \%$ for the intercrop treatment with grain sorghum (Table 1). However, border crop treatments had no effect on AUDPC or final disease incidence. Yield of fruit with virus symptoms, which ranged from $40 \%$ of the total yield for the intercrop treatment to $80 \%$ of the total yield for the corn-border treatment, did not differ among treatments. Yield of healthy fruit and total yield for the corn border were reduced compared with the untreated control, but did not differ among the control and the other treatments.

Bixby and Lane - 1997. Virus diseases developed at both locations, but disease incidence in the control plots did not reach $100 \%$ as in 1996 (Fig. 3C and D). At Bixby, nearly all (99\%) of the 518 plants assayed by ELISA were positive for WMV. WMV was detected alone in $76 \%$ of samples, with ZYMV in $13 \%$ of samples, and with PRSV-W in $11 \%$ of samples. PRSV$\mathrm{W}$ alone was found in less than $1 \%$ of the samples. At Lane, both PRSV-W and WMV were predominant. Both viruses were detected in $38 \%$ of plants, and WMV and PRSV-W were found alone in 32 and $26 \%$ of plants, respectively. ZYMV and CMV were detected in 3 and $<1 \%$ of samples, respectively.

Aphid immigration into plots, as determined by trap catches, occurred throughout the season at each location. However, maximum trap catches occurred on $4 \mathrm{Au}$ gust at Bixby (Fig. 3A) and from 5 to 14 August at Lane (Fig. 3B). Peak trap catches preceded the periods of increase in virus disease incidence at Bixby (Fig. 3C) and Lane (Fig. 3D). Trap catches were low ( $<5$ per trap) during other periods of the season. Aphid landing rates ranged from 2.2 to 4.6 aphids/week at Bixby and 1.6 to 2.9 aphids/week at Lane and did not differ among treatments at either location.

At Bixby, virus disease first appeared in the control plots and the late-planted border treatment on 4 August (Fig. 3C). Disease incidence increased to over $80 \%$ by 13 September. Except for the late-planted border treatment, border and intercrop treatments resulted in a 7- to 21-day delay in the appearance of disease (Fig. 3C). At Lane, symptoms first appeared in the control and border treatments on 20 August (Fig 3D). Disease incidence in the control increased to $61 \%$ by 22 September. Intercrop but not border treatments delayed the first appearance of symptoms by 7 days. All of the intercrop and border treatments, except for the early-planted border treatment at Lane, resulted in a reduction of $50 \%$ or more in both AUDPC and final disease incidence compared with the control at both locations (Table 2). The early and late-planted intercrop treatments receiving grass-selective herbicide at Lane, and the intercrop treatment that was mowed at Bixby, provided the greatest reductions in virus disease. However, the herbicide-treated intercrop treatments at Bixby were less effective than in 1996. The planting date of the companion crop
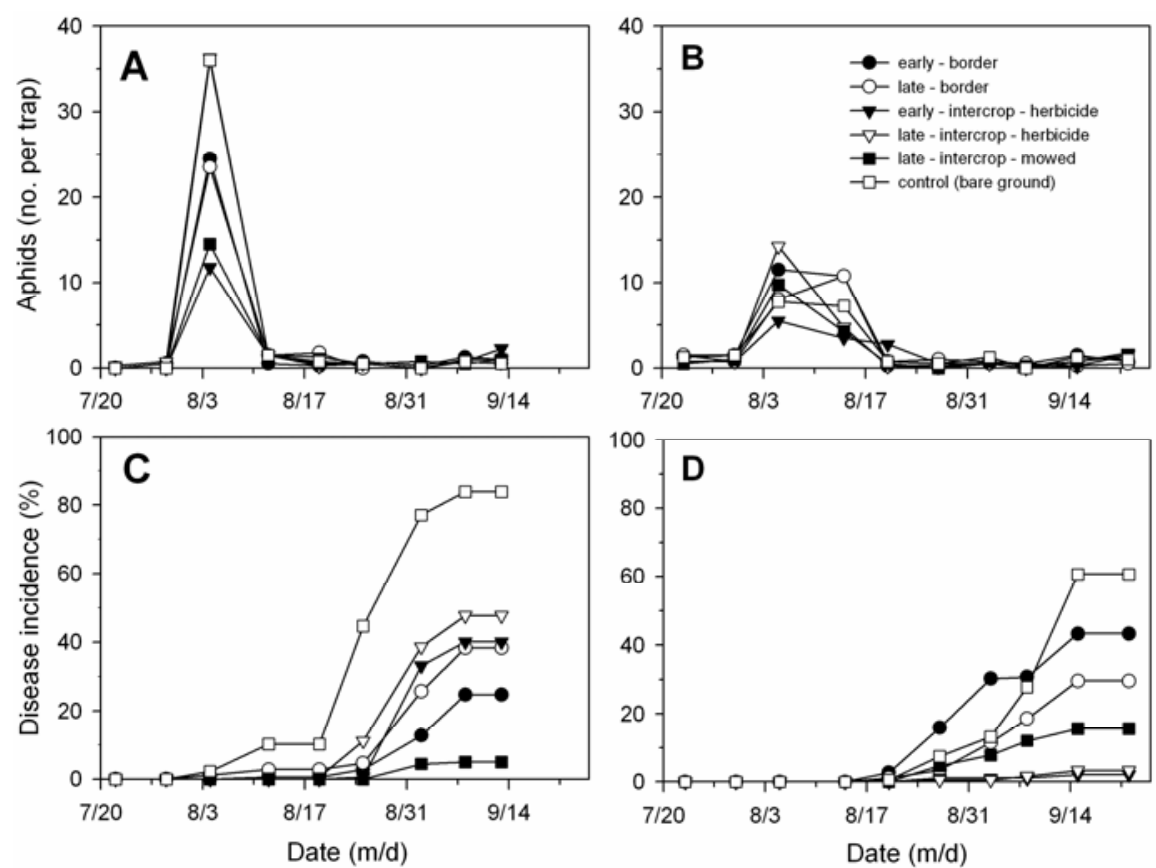

Fig. 3. Effects of grain sorghum planted in border and intercrop patterns with pumpkin on alate aphid immigration at $\mathbf{A}$, Bixby and $\mathbf{B}$, Lane and on progress of virus diseases of pumpkin at $\mathbf{C}$, Bixby and $\mathbf{D}$, Lane in 1997. Grain sorghum was planted ca. 2 weeks before (early) or on the same (late) planting date as pumpkin. Methods of alleviating competition between the intercrop and pumpkin were grassselective herbicide (herbicide) and mowing.

appeared to have little effect on virus disease control. Except for an increase in AUDPC at Lane for the early-planted border compared with the late-planted border, there were no differences in AUDPC or final disease incidence between early and late planting dates for border or intercrop treatments.

Yield could not be determined at Bixby because of severe development of bacterial leaf spot caused by Xanthomonas campestris pv. cucurbitae. The disease appeared at midseason and resulted in extensive fruit rot at harvest. At Lane, all of the treatments reduced yield of fruit with virus symptoms compared with the control $(\mathrm{Ta}-$ ble 2). However, none of the treatments resulted in greater yields of healthy fruit or total fruit compared with the control (Table 2). All of the treatments except the lateplanted border had lower yields compared

Table 1. Influence of border crops and an intercrop on control of virus diseases of pumpkin in 1996

\begin{tabular}{|c|c|c|c|c|c|c|}
\hline \multirow[b]{2}{*}{ Crop } & \multirow[b]{2}{*}{ Pattern $^{u}$} & \multirow{2}{*}{$\begin{array}{c}\text { Disease incidence } \\
(\%)^{\mathrm{v}}\end{array}$} & \multirow[b]{2}{*}{ AUDPC $^{w}$} & \multicolumn{3}{|c|}{ Pumpkin yield (t/ha) } \\
\hline & & & & $\operatorname{Virus}^{x}$ & Healthy & Total \\
\hline Soybean & Border & $98.1 \mathrm{a}^{\mathrm{y}}$ & $1718.5 \mathrm{a}$ & $4.28 \mathrm{a}$ & $4.41 \mathrm{a}$ & $8.69 a$ \\
\hline Corn & Border & $96.6 \mathrm{a}$ & $1837.7 \mathrm{a}$ & $3.25 \mathrm{a}$ & $0.86 \mathrm{~b}$ & $4.11 \mathrm{~b}$ \\
\hline Peanut & Border & $96.5 \mathrm{a}$ & $1764.3 \mathrm{a}$ & $5.88 \mathrm{a}$ & $3.93 \mathrm{a}$ & $9.81 a$ \\
\hline Grain sorghum & Intercrop & $35.6 \mathrm{~b}$ & $458.6 \mathrm{~b}$ & $4.32 \mathrm{a}$ & $6.37 \mathrm{a}$ & $10.69 a$ \\
\hline None & Bare ground & $100.0 \mathrm{a}$ & $1854.6 \mathrm{a}$ & $5.21 \mathrm{a}$ & $6.06 \mathrm{a}$ & $11.26 a$ \\
\hline $\operatorname{LSD}(P \leq 0.05)$ & & 6.9 & 193.1 & $\mathrm{NS}^{\mathrm{z}}$ & 3.03 & 3.52 \\
\hline
\end{tabular}

"Crops were grown in a pattern with pumpkin (see Fig. 1).

${ }^{\mathrm{v}}$ Final incidence of symptomatic plants confirmed positive with enzyme-linked immunosorbent assay.

${ }^{\mathrm{w}}$ Area under the disease progress curve.

${ }^{\mathrm{x}}$ Fruit with virus symptoms.

${ }^{y}$ Values, the means of three replications per treatment, followed by the same letter are not significantly different according to Fisher's least significant difference (LSD) test at $P \leq 0.05$.

${ }^{z}$ Treatment effect not significant at $P \leq 0.05$. 
with the control. Reductions in total yield of $50 \%$ or more were observed in the intercrop treatments. The early planting date for both the border and intercrop treatments had reduced total yield compared with respective late planting dates. The planting date effect was most pronounced for the intercrop pattern, with almost no yield produced for the early planting date.

Bixby and Lane - 1998. The incidence of virus diseases at both locations was similar to that observed in 1997. WMV was detected most frequently at both locations, although a wide range of viruses were present. Of the 469 plants assayed at Bixby, WMV alone occurred at a frequency of $52 \%$, SqMV alone at $6 \%$, and PRSV-W alone at less than $1 \%$. WMV and SqMV were detected together in $27 \%$ of samples. The remaining $15 \%$ of plants had WMV in various combinations with PRSV-W, SqMV, and/or ZYMZ. Of the 363 plants assayed at Lane, $79 \%$ were positive for WMV alone, 3\% for SqMV alone, and $1 \%$ each for PRSV-W, ZYMV, and CMV alone. The remaining $15 \%$ of samples had WMV in various combinations with PRSV-W, SqMV, CMV, and/or ZYMZ.

Aphids were trapped throughout the season at both locations except for the first sampling date at Lane. Maximum periods of aphid immigration occurred from 6 to 12 August at Bixby (Fig. 4A), and on 12 August at Lane (Fig. 4B). However, levels of aphid immigration during the peak periods were lower at both locations than in 1997. Peak immigration occurred simultaneously with virus symptom appearance at Bixby (Fig. 4C), but preceded symptom appearance by 14 days at Lane (Fig. 4D). Aphid landing rates ranged from 0.7 to 1.3 aphids/week at Bixby and from 0.3 to 0.7 aphids/week at Lane and did not differ among treatments.

At Bixby, virus disease appeared in the control on 27 August and increased to over $80 \%$ by 25 September (Fig. 4C). Symptom appearance for the high and low seeding rates of grain sorghum, but not the other intercrop treatments, was delayed by 9 days. All of the intercrop treatments except peanut reduced AUDPC compared with the
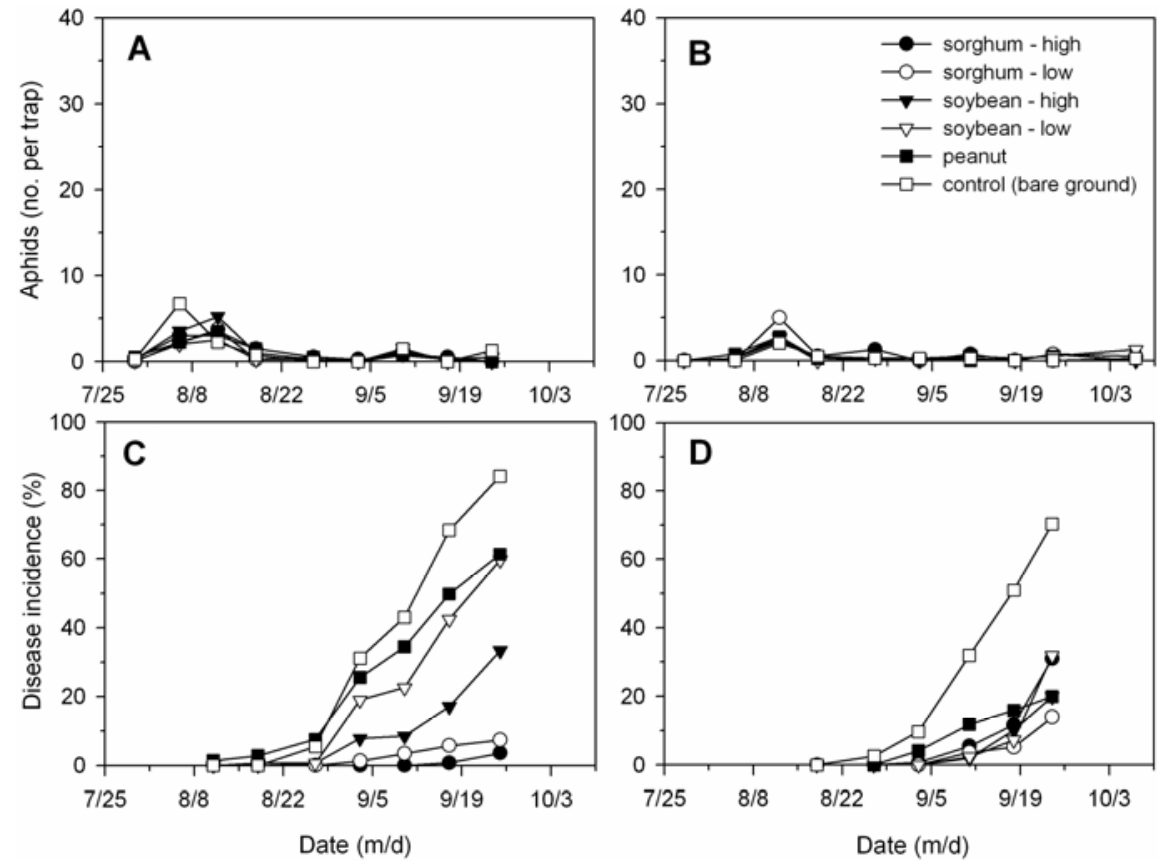

Fig. 4. Effects of intercrops and their seeding rate (high versus low) on alate aphid immigration at $\mathbf{A}$, Bixby and $\mathbf{B}$, Lane and on progress of virus diseases of pumpkin at $\mathbf{C}$, Bixby and $\mathbf{D}$, Lane in 1998 . control, and all reduced final disease incidence (Table 3). Both early and late planted treatments with grain sorghum had final disease incidences of less than $10 \%$. At Lane, symptoms appeared in control plots on 20 August and reached $70 \%$ by 24 September (Fig. 4). Intercrop treatments delayed disease development by 7 to 14 days. All of the intercrop treatments reduced AUDPC and final disease incidence (Table 3). The low seeding rate of grain sorghum and the peanut intercrop treatments had the lowest final disease inci-

Table 2. Influence of cropping patterns with grain sorghum on control of virus diseases of pumpkin at Lane and Bixby in 1997

\begin{tabular}{|c|c|c|c|c|c|c|}
\hline \multirow[b]{2}{*}{ Pattern $^{t}$} & \multirow[b]{2}{*}{ Type $^{\mathbf{u}}$} & \multirow{2}{*}{$\begin{array}{l}\text { Disease incidence } \\
(\%)^{\mathrm{v}}\end{array}$} & \multirow[b]{2}{*}{ AUDPC $^{w}$} & \multicolumn{3}{|c|}{ Pumpkin yield (t/ha) } \\
\hline & & & & $\operatorname{Virus}^{x}$ & Healthy & Total \\
\hline \multicolumn{7}{|l|}{ Lane } \\
\hline Border & Early & $43.3 b^{y}$ & $949.1 \mathrm{a}$ & $6.16 \mathrm{bc}$ & $13.14 \mathrm{~b}$ & $19.30 \mathrm{~b}$ \\
\hline Border & Late & $29.6 \mathrm{bc}$ & $522.6 \mathrm{~b}$ & $8.19 \mathrm{~b}$ & $19.26 \mathrm{a}$ & $27.44 \mathrm{a}$ \\
\hline Intercrop & Early-herbicide & $2.1 \mathrm{~d}$ & $41.7 \mathrm{c}$ & $0.36 \mathrm{e}$ & $0.25 \mathrm{~d}$ & $0.62 \mathrm{~d}$ \\
\hline Intercrop & Late-herbicide & $3.3 \mathrm{~d}$ & $51.4 \mathrm{c}$ & $3.14 \mathrm{de}$ & $10.90 \mathrm{bc}$ & $14.04 \mathrm{bc}$ \\
\hline Intercrop & Late-mowed & $15.6 \mathrm{~cd}$ & $316.5 \mathrm{bc}$ & $3.93 \mathrm{~cd}$ & $7.42 \mathrm{c}$ & $11.35 \mathrm{c}$ \\
\hline Bare ground & $\ldots$ & $60.7 \mathrm{a}$ & 939.7 a & $10.66 \mathrm{a}$ & $16.54 \mathrm{ab}$ & $28.40 \mathrm{a}$ \\
\hline $\operatorname{LSD}(P \leq 0.05)$ & & 16.9 & 409.8 & 2.89 & 5.57 & 5.39 \\
\hline \multicolumn{7}{|l|}{ Bixby } \\
\hline Border & Early & $24.7 \mathrm{c}$ & $315.0 \mathrm{~cd}$ & $\ldots{ }^{\mathrm{z}}$ & $\ldots$ & $\ldots$ \\
\hline Border & Late & $38.3 \mathrm{bc}$ & $566.0 \mathrm{bc}$ & $\ldots$ & $\ldots$ & $\ldots$ \\
\hline Intercrop & Early-herbicide & $40.0 \mathrm{bc}$ & $556.5 \mathrm{bc}$ & $\ldots$ & $\ldots$ & $\ldots$ \\
\hline Intercrop & Late-herbicide & $47.7 \mathrm{~b}$ & $738.7 \mathrm{~b}$ & $\ldots$ & $\ldots$ & $\ldots$ \\
\hline Intercrop & Late-mowed & $5.0 \mathrm{~d}$ & $71.2 \mathrm{~d}$ & $\ldots$ & $\ldots$ & $\ldots$ \\
\hline Bare ground & $\ldots$ & $83.9 \mathrm{a}$ & $1684.2 \mathrm{a}$ & $\ldots$ & $\ldots$ & $\ldots$ \\
\hline $\operatorname{LSD}(P \leq 0.05)$ & & 18.7 & 328.4 & & & \\
\hline \multicolumn{7}{|c|}{ Grain sorghum was grown in a pattern with pumpkin (see Fig. 1). } \\
\hline \multirow{2}{*}{\multicolumn{7}{|c|}{$\begin{array}{l}\text { u Grain sorghum was planted } 2 \text { weeks before (early) or at pumpkin planting (late). For the intercrop treatments, competition between grain sorghum and } \\
\text { pumpkin was reduced along pumpkin rows with postemergence herbicide or mowing. }\end{array}$}} \\
\hline & & & & & & \\
\hline \multicolumn{7}{|c|}{ v Final incidence of symptomatic plants confirmed positive with enzyme-linked immunosorbent assay. } \\
\hline \multicolumn{7}{|c|}{${ }^{w}$ Area under the disease progress curve. } \\
\hline \multicolumn{7}{|c|}{$\mathrm{x}$ Yield of fruit with virus symptoms. } \\
\hline \multicolumn{7}{|c|}{$\begin{array}{l}\text { y Values, the means of three replications per treatment, followed by the same letter are not significantly different according to Fisher's least significant differ- } \\
\text { ence (LSD) test at } P \leq 0.05 \text {. }\end{array}$} \\
\hline
\end{tabular}


dence. Seeding rate of the intercrops did not consistently influence virus disease levels. The high seeding rate for soybean resulted in lower AUDPC and final disease incidence at Bixby, but not at Lane. Conversely, the low seeding rate of grain sorghum had a lower final disease incidence at Lane, but not at Bixby.

The incidence of fruit with virus symptoms in 1998 at both locations was less than in the two previous years (Table 3). All of the intercrop treatments except the high seeding rate of soybean at Bixby and the peanut and soybean treatments at Lane reduced yield of symptomatic fruit. At Bixby, yield of healthy fruit was increased by the soybean and peanut intercrops, but not by the grain sorghum treatments. Total yields for the intercrop treatments did not differ at Bixby except for the high seeding rate of grain sorghum, which had a $30 \%$ lower yield than the control. At Lane, however, all of the intercrop treatments except the low seeding rate of soybean reduced yield of healthy fruit and total yield. Yield reductions ranged from 30\% for the high seeding rate of soybean to $80 \%$ for the high rate of grain sorghum.

\section{DISCUSSION}

The manipulation of cropping patterns through the use of companion crops as intercrops, and to a lesser extent as crop borders, reduced the incidence of nonpersistent, aphid-transmitted viruses of pumpkin in five trials over 3 years compared with clean tillage. An intercrop treatment of grain sorghum was included in each trial and resulted in significant reductions in the AUDPC that ranged from 56 to $98 \%$. In the first year, border-crop patterns with corn, soybeans, and peanuts selected in part for their differential plant heights, were not effective compared to the intercrop treatment with grain sorghum. However, when grain sorghum was planted as a crop border the following year, final disease incidence was less than the control at both locations, while AUDPC was reduced for one of two planting dates at Lane and for both planting dates at Bixby. These results suggest that selection of the companion crop when planted as a crop border for virus disease control in cucurbits is important. In the third year of the study, intercrops of soybeans and peanuts, which were not effective when previously deployed as border crops, generally resulted in reduced virus disease incidence in the two locations. The soybean groundcover reduced AUDPC from 39 to $82 \%$ compared with the controls, but the peanut groundcover only reduced AUDPC at Lane. These results suggest that companion crop selection for virus disease control in cucurbits with intercropping may not be as critical as border crop selection.

The choice of a border crop was not important in protection of potatoes from PVY (8). In that study, aphid landing in the center of potato plots was not affected by border treatments; however, aphid landing was reduced in borders planted with soybean, sorghum, or wheat compared with fallowed borders. The virus control observed in that study was attributed to decreased aphid landing at the edges of plots planted with crop borders and a resulting reduced level of virus in edge rows near the planted borders. The crop borders thus eliminated bare soil/crop interfaces reported to be attractive to alate aphids. Pepper rows adjacent to sunflower borders also were reported to have reduced levels of PVY infection (28). Aphid landing in the borders was not monitored in our study, and obvious edge effects were not observed within plots. In contrast to other crop/virus systems where border crops have been tested, cucurbits are widely spaced both within and between rows. Thus, contrasting plant and soil interfaces are abundant until canopy closure. Complete canopy closure both within and between rows typically occurred in mid to late August, shortly after aphid landing peaked during the first 2 weeks of August at both locations in 1997 and 1998. Thus, the effectiveness of a crop border in altering alate aphid behavior in cucurbits may be less than that for more closely spaced row crops.

Although grain sorghum was not directly compared to peanut, soybean, and corn as a crop border, its use as a crop border had beneficial effects on virus disease incidence in this study. The effectiveness of sorghum as a crop border and intercrop in managing nonpersistent virus disease has been reported in several other studies $(3,8,10)$. In the management of PVY and CMV in pepper, borders of sorghum were more effective than corn (10). Its effectiveness against cucurbit viruses in this study may be related to feeding preference of aphid vectors. It is possible that sorghum is a preferred host of a key vector species and subsequent further flight is deterred once sorghum is probed. In the intercropping of soybean with sorghum that reduced SMV (2), the corn leaf aphid (Rhopalosiphum maydis), a vector of SMV and a primary pest of sorghum, was abundant in the intercropped sorghum, suggesting that it may have acted to hold a key aphid vector. A limitation of our study was that we were unable to identify the aphids trapped and thus are unsure of the key vector species contributing to the spread of

Table 3. Influence of intercrops and their seeding rate on control of virus diseases of pumpkin at Lane and Bixby in 1998

\begin{tabular}{|c|c|c|c|c|c|c|}
\hline \multirow[b]{2}{*}{ Crop $^{u}$} & \multirow{2}{*}{$\begin{array}{l}\text { Pattern and } \\
\text { seeding rate }^{v}\end{array}$} & \multirow{2}{*}{$\begin{array}{l}\text { Disease incidence } \\
(\%)^{\mathrm{w}}\end{array}$} & \multirow[b]{2}{*}{$\operatorname{AUDPC}^{\mathbf{x}}$} & \multicolumn{3}{|c|}{ Pumpkin yield (t/ha) } \\
\hline & & & & Virus $^{y}$ & Healthy & Total \\
\hline \multicolumn{7}{|l|}{ Lane } \\
\hline Grain sorghum & Intercrop-H & $31.0 \mathrm{~b}^{\mathrm{z}}$ & $215.1 \mathrm{~b}$ & $0.43 \mathrm{~b}$ & $2.89 \mathrm{~d}$ & $3.32 \mathrm{e}$ \\
\hline Grain sorghum & Intercrop-L & $14.0 \mathrm{c}$ & $103.2 \mathrm{~b}$ & $0.52 \mathrm{~b}$ & $4.90 \mathrm{~cd}$ & $5.42 \mathrm{de}$ \\
\hline Soybean & Intercrop-H & $29.5 \mathrm{bc}$ & $169.4 \mathrm{~b}$ & $2.13 \mathrm{a}$ & $10.05 \mathrm{~b}$ & $12.18 \mathrm{bc}$ \\
\hline Soybean & Intercrop-L & $31.9 \mathrm{~b}$ & $160.8 \mathrm{~b}$ & $1.77 \mathrm{ab}$ & $12.60 \mathrm{ab}$ & $14.38 \mathrm{ab}$ \\
\hline Peanut & Intercrop-H & $20.0 \mathrm{bc}$ & $283.2 \mathrm{~b}$ & $1.29 \mathrm{ab}$ & $8.25 \mathrm{bc}$ & $9.55 \mathrm{~cd}$ \\
\hline None & Bare ground & $70.3 \mathrm{a}$ & $875.4 \mathrm{a}$ & $2.56 \mathrm{a}$ & $14.89 \mathrm{a}$ & $17.45 \mathrm{a}$ \\
\hline $\operatorname{LSD}(P \leq 0.05)$ & & 16.0 & 250.4 & 1.42 & 4.40 & 4.57 \\
\hline \multicolumn{7}{|l|}{ Bixby } \\
\hline Grain sorghum & Intercrop-H & $3.6 \mathrm{~d}$ & $19.9 \mathrm{~d}$ & $0.44 \mathrm{c}$ & $6.22 \mathrm{~b}$ & $6.66 \mathrm{~b}$ \\
\hline Grain sorghum & Intercrop-L & $7.4 \mathrm{~d}$ & $105.3 \mathrm{~cd}$ & $0.46 \mathrm{c}$ & $8.86 \mathrm{ab}$ & $9.32 \mathrm{ab}$ \\
\hline Soybean & Intercrop-H & $33.3 \mathrm{c}$ & $387.0 \mathrm{c}$ & $0.95 \mathrm{bc}$ & $12.13 \mathrm{a}$ & $13.08 \mathrm{a}$ \\
\hline Soybean & Intercrop-L & $59.7 \mathrm{~b}$ & $853.1 \mathrm{~b}$ & $1.13 \mathrm{bc}$ & $11.00 \mathrm{a}$ & $12.13 \mathrm{a}$ \\
\hline Peanut & Intercrop-H & $61.4 \mathrm{~b}$ & $1128.1 \mathrm{ab}$ & $1.95 \mathrm{ab}$ & $11.16 \mathrm{a}$ & $13.11 \mathrm{a}$ \\
\hline None & Bare ground & $84.1 \mathrm{a}$ & $1412.0 \mathrm{a}$ & $2.89 \mathrm{a}$ & $7.02 \mathrm{~b}$ & $9.91 \mathrm{ab}$ \\
\hline $\operatorname{LSD}(P \leq 0.05)$ & & 13.1 & 319.1 & 1.14 & 3.61 & 3.95 \\
\hline
\end{tabular}

${ }^{u}$ Crops grown with pumpkin (see Fig. 1).

${ }^{\mathrm{v}}$ High $(\mathrm{H})$ and low $(\mathrm{L})$ seeding rates.

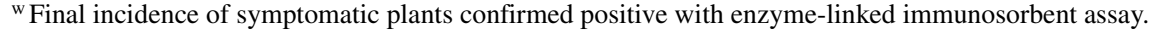

${ }^{x}$ Area under the disease progress curve.

y Yield of fruit with virus symptoms.

${ }^{\mathrm{z}}$ Values, the means of three replications per treatment, followed by the same letter are not significantly different according to Fisher's least significant difference (LSD) test at $P \leq 0.05$. 
cucurbit viruses locally. However, differences in host ranges of known aphid vectors among the companion crops evaluated in this study do not suggest that feeding preference played a large role in the observed virus disease control. Of the 14 aphid species reported on sorghum (2), only the bird cherry oat aphid (Rhopalosiphum padi) is a reported vector of WMV (22). Soybean, corn, and peanuts are hosts of multiple known vectors of WMV including the green peach aphid (Myzus persicae) and/or the melon/cotton aphid (Aphis gossypii) $(2,22)$.

The virus disease control with intercrop and crop border treatments in this study did not appear to be related to levels of alate aphids landing in plots. Aphid landing rates in the center of plots did not differ among cropping pattern treatments. Except for the reduced aphid landing rates in borders of potato plots protected by crop borders (8), crop border treatments have had little or no impact on aphid landing rates in other studies $(10,16)$. Sylvester (30) concluded that alate trap catches are better correlated with spread of semipersistent and persistent viruses than nonpersistent viruses. The virus disease reduction observed with companion crop treatments in this study was more likely due to a reduced probability of viruliferous aphids landing and probing on the cucurbit host plants through their interception on the intercrops and to a lesser extent on the border crops. Once intercepted on a companion crop, reduced aphid infectivity likely resulted following probing of the nonhost plants. Fereres (10) reported that the transmission efficiency of PVY and CMV to pepper by both the green peach aphid and the melon/cotton aphid was reduced by $50 \%$ or more when aphids had access periods to corn and sorghum prior to ultimate access to pepper. He concluded that border crops serve as "virus sinks" in which the ability to transmit virus is lost during probing. Conversely, Simmons (28) proposed that tall border crops such as sunflower formed a physical barrier to alate aphid landing, which resulted in delayed virus development in pepper. Our results and those of DiFonzo et al. (8) suggest that the height of a crop border is not important for virus disease control. Of the border crops tested in 1996, corn provided the tallest barrier to alate landing. While virus disease severity was not evaluated in this study, symptoms were most severe and yield was lowest in plots bordered by corn. Unfortunately, we did not trap aphids in the first year of this study. However, corn may have served as a windbreak promoting the accumulation of alate aphids $(1,17)$.

Despite the reduced virus disease incidences observed with intercrops and some border crops in our study, yield benefits were not generally observed. Yield of healthy fruit was greater than the control only for intercrop patterns of soybean and peanut at Bixby in 1998. Intercrop treatments resulted in reduced yields at Lane with sorghum in both 1997 and 1998, and with peanut in 1998. While growth of pumpkin plants was not measured as a treatment response, reduced growth was observed for intercrops of grain sorghum in most of the trials. The negative effect of crop competition on yield was particularly severe when the grain sorghum intercrop was planted before pumpkins, and also was evident for the early planting of sorghum as a border crop. Attempts were made to reduce the effects of crop competition by using grass-selective herbicide along rows and by mowing between rows. The objective was to increase the space for vine growth as the season progressed while minimizing the distinct interface between bare soil and plants reported to be attractive to alate aphids. In 1996, when yields for the intercrop treatment did not differ from the control plots, pumpkin vines covered the herbicide-treated area and grew up and over the intercrop. In 1997, vine growth was restricted to the treated strips and yield reductions were severe. Mowing did not alleviate the effects of crop competition, as its effect on sorghum growth was temporary. In addition to the negative competitive effects, the planting of the groundcover before the cucurbit crop provided no apparent benefit in virus disease control. In 1998, reduced seeding rates of the groundcover crops were used in an attempt to reduce crop competition effects. While there were trends for increased yield with reduced seeding rates, the yields did not significantly differ. Muskmelon yields with groundcover treatments of wheat and Swiss chard, planted 1 month before the crop, also reduced yields despite providing a high level of disease control (33). In the muskmelon study, the wheat intercrop apparently delayed fruit maturity, and most of the fruit were immature when the experiment was terminated. Methods of alleviating the effects of crop competition in that study included applying a growth retardant to wheat, thinning the intercrop crops around the cucurbit plants, and trimming to reduce plant height.

Incidence of virus disease was severe in each of the experiments over a 3-year period, demonstrating the chronic nature of potyvirus diseases in summer and fall cucurbit production in Oklahoma. Overall, WMV and PRSV-W were the most frequently detected viruses, as previously noted in a virus survey of cucurbits in Oklahoma (37). However, a wider range of viruses was detected in some of the trials in this study. ZYMV and CMV, not detected in the previous survey, were generally found at a low frequency and in mixed infections. SqMV, also not detected in the previous survey, was detected in three of the trials, and was found in $30 \%$ of plants sampled at Bixby in 1998. However, its incidence in the intercrop treatments was less than $10 \%$.

Companion crops were selected that were compatible with an effective preemergence herbicide (metolachlor) that can be safely used, but is not registered for use on cucurbits. Grain sorghum seed was treated with cyometrinil, a herbicide safener that permitted sorghum germination and growth through metolachlortreated soil. Generally, weed control was adequate with this program, although lateseason emergence of Palmer amaranth, particularly with control and border crop treatments, necessitated hoeing. Halosulfuron-methyl is now registered for use on both cucurbits and grain sorghum, and provides excellent control of Palmer amaranth. This herbicide does not provide control of grassy weeds, which might permit greater compatibility with grassy companion crops.

Alterations of cucurbit cropping patterns using intercrops and crop borders with sorghum were effective in reducing nonpersistent virus diseases. However, overcoming problems with intercrop competition and the resulting reduced yields observed in this study would be necessary before such systems could be recommended. Because pumpkins grow more vigorously than other cucurbit crops, it is likely that negative effects of crop competition, particularly with intercrop treatments, would be more severe on cucurbit crops such as watermelon and cantaloupe. Further research evaluating additional intercrops and lower seeding rates than those evaluated in this study might be beneficial. The border crop pattern would be more adaptable to commercial application. Watermelon growers in the region already use fall-planted small grains (wheat, rye) as windbreaks in the production of early-season watermelons. The wider strips of border crops used in other studies $(8,16,28)$ might prove more effective than those reported here.

\section{ACKNOWLEDGMENTS}

Approved for publication by the Director, Oklahoma Agricultural Experiment Station. This research was funded in part by the Agricultural Experiment Station project H2159 and CSREES So. Region IPM agreement \#96-34103-3280.

\section{LITERATURE CITED}

1. Alderz, W. C. 1974. Wind effects on spread of watermelon mosaic virus 1 from local virus sources to watermelon. J. Econ. Entomol. 67:361-364.

2. Blackman, R. L., and Eastop, V. F. 2000. Aphids on the World's Crops: An Identification and Information Guide, 2nd ed. John Wiley \& Sons, Ltd., West Sussex, England.

3. Bottenberg, H., and Irwin, M. E. 1992. Using mixed cropping to limit seed mottling induced by soybean mosaic virus. Plant Dis. 76:304306.

4. Campbell, R. N. 1971. Squash mosaic virus. Descriptions of Plant Viruses, no. 43. Commonw. Mycol. Inst./Assoc. Appl. Biol., Kew, England. 
5. Chala, V. H., Harrison, C. W., and Halliwell, R. S. 1987. Identification of two distinct strains of watermelon mosaic virus 2 affecting cucurbits in Texas. Plant Dis. 71:750-752.

6. Conway, K. E., McCraw, B. D., Motes, J. E., and Sherwood, J. L. 1989. Evaluations of mulches and row covers to delay virus diseases and their effects on yield of yellow squash. Appl. Agric. Res. 4:201-207.

7. Davis, R. F., and Mizuki, M. K. 1987. Detection of cucurbit viruses in New Jersey. Plant Dis. 71:40-44.

8. DiFonzo, C. D., Ragsdale, D. W., Radcliffe, E. B., Gudmestad, N. C., and Secor, G. A. 1996. Crop borders reduce potato virus $\mathrm{Y}$ incidence in seed potato. Ann. Appl. Biol. 129:289-302.

9. Edwards, M. L., and Cooper, J. I. 1985. Plant virus detection using a new form of indirect ELISA. J. Virol. Methods 11:309-319.

10. Fereres, A. 2000. Barrier crops as a cultural control measure of non-persistently transmitted aphid-borne viruses. Virus Res. 71:221-231.

11. Francki, R. I. B., Mossop, D. W., and Hatta, T. 1979. Cucumber mosaic virus. Descriptions of Plant Viruses, no. 213 (no. 1, rev.). Commonw. Mycol. Inst./Assoc. Appl. Biol., Kew, England.

12. Fuchs, M., Tricoli, D. M., Carney, K. J., Schesser, M., McFerson, J. R., and Gonsalves, D. 1998. Comparative virus resistance and fruit yield of transgenic squash with single and multiple coat protein genes. Plant Dis. 82:1350-1356

13. Green, S. K. 1991. Integrated control of virus diseases of vegetables in Taiwan. Pages 35-68 in: Proc. 1990 Int. Workshop Implementation Integr. Control Virus Dis. Important Crops, Taichung, Taiwan.

14. Halliwell, R. S., Johnson, J., and Cotner, S. 1979. Watermelon mosaic virus disease of squash, watermelon, and pumpkin. Texas Agric. Exp. Stn. Misc. Pub. no. 1435

15. Harveson, R. M., Halliwell, R. S., and Johnson, J. 1990. The identification and distribution of cucurbit viruses in Texas. Texas Agric. Exp. Stn. Misc. Pub. no. 1698
16. Jayasena, K. W., and Randles, J. W. 1985. The effects of insecticides and a plant barrier row on aphid populations and spread of bean yellow mosaic potyvirus and subterranean clover red leaf luteovirus in Vicia faba in South Australia. Ann. Appl. Biol. 107:355-364.

17. Klingauf, F. A. 1987. Host plant finding and acceptance. Pages 209-220 in: Aphids: Their Biology, Natural Enemies and Control, Vol. 2A. A. K. Minks and P. Harrewijn, eds. Elsevier, New York

18. Lisa, V., Boccardo, G., D'Agostino, G., Dellavalle, G., and d'Aquilio, M. 1981. Characterization of a potyvirus that causes zucchini yellow mosaic. Phytopathology 71:667-672.

19. Lisa, V., and Lecoq, H. 1984. Zucchini yellow mosaic. Descriptions of Plant Viruses, no. 282. Commonw. Mycol. Inst./Assoc. Appl. Biol., Kew, England.

20. Maelzer, D. A. 1986. Integrated control of insect vectors of plant virus diseases. Pages 483-512 in: Plant Virus Epidemics: Monitoring, Modeling and Predicting Epidemics. G. D. McLean, R. G. Garrett, and W. G. Ruesink eds. Academic Press, New York.

21. Matthews, R. E. F. 1970. Plant Virology. Academic Press, New York.

22. Perring, T. M., Farrar, C. A., Mayberry, K., and Blua, M. J. 1992. Research reveals pattern of cucurbit virus spread. Calif. Agric. 46:35-40.

23. Purcifull, D. E., Gonsalves, D., Edwardson, J., and Heibert, E. 1984. Papaya ringspot virus. Descriptions of Plant Viruses, no. 292 (no. 84, rev.). Commonw. Mycol. Inst./Assoc. Appl. Biol., Kew, England.

24. Purcifull, D. E., Hiebert, E., and Edwardson, J. 1984. Watermelon mosaic virus 2. Descriptions of Plant Viruses, no. 293 (no. 63, rev.). Commonw. Mycol. Inst./Assoc. Appl. Biol., Kew, England.

25. Sammons, B., Barnett, O. W., Davis, R. F., and Mizuki, M. K. 1989. A survey of viruses infecting yellow summer squash in South Carolina. Plant Dis. 73:401-404.

26. Shaner, G., and Finney, R. E. 1977. The effect of nitrogen fertilization on the expression of slow-mildewing in Knox wheat. Phytopathology 67:1051-1056.

27. Sherf, A. F., and MacNab, A. A. 1986. Vegetable Diseases and Their Control, 2nd ed. John Wiley \& Sons, New York.

28. Simmons, J. N. 1957. Effects of insecticides and physical barriers on field spread of pepper veinbanding mosaic virus. Phytopathology 47:139-145

29. Simmons, J. N., and Zitter, T. A. 1980. Use of oils to control aphid-borne viruses. Plant Dis. 64:542-546.

30. Sylvester, E. S. 1989. Viruses transmitted by aphids. Pages 65-87 in: Aphids: Their Biology, Natural Enemies and Control, Vol. 2C. A. K. Minks and P. Harrewijn, eds. Elsevier, New York.

31. Taylor, L. R. 1986. The distribution of virus disease and the migrant vector aphid. Pages 35-57 in: Plant Virus Epidemics: Monitoring, Modeling and Predicting Epidemics. G. D McLean, R. G. Garrett, and W. G. Ruesink, eds. Academic Press, New York.

32. Thresh, J. M. 1982. Cropping practices and virus spread. Annu. Rev. Phytopathol. 20:193218.

33. Toba, H. H., Kishaba, A. N., Bohn, G. W., and Hield, H. 1977. Protecting muskmelon against aphid-borne viruses. Phytopathology 67:1418-1423.

34. Ullman, D. E., Cho, J. J., and German, T. L. 1991. Occurrence and distribution of cucurbit viruses in the Hawaiian Islands. Plant Dis. 75:367-370.

35. Umesh, K. C., Valencia, J., Hurley, C., Gubler, W. D., and Falk, B. W. 1995. Stylet oil provides limited control of aphid-transmitted viruses in melons. Calif. Agric. 49:22-24.

36. Webb, S. E., and Linda, S. B. 1993. Effect of oil and insecticide on epidemics of potyviruses in watermelon in Florida. Plant Dis. 77:869-874.

37. Yilmaz, S. 1996. Survey for viruses in cucurbits in Oklahoma. M.S. thesis. Oklahoma State University, Stillwater. 